\title{
Environmental Pollution Monitoring of the Chechen Republic (within the period of 2015-2017)
}

Sedieva M.B.

Department of geology, geophysics and eco-geology Complex Research Institute named after Kh.I. Ibragimov of the Russian Academy of Sciences Grozny, Russia milann_s@mail.ru

\section{Islamov D.A.}

Department of geology, geophysics and eco-geology Complex Research Institute named after Kh.I. Ibragimov of the Russian Academy of Sciences

Grozny, Russia

dena1928@mail.ru

\author{
Gayrabekov U.T. \\ Department of geology, geophysics and eco-geology \\ Complex Research Institute named after Kh.I. Ibragimov of \\ the Russian Academy of Sciences \\ the Academy of Sciences of the Chechen Republic \\ Chechen State University \\ Grozny, Russia \\ gairabekov_u@mail.ru
}

\author{
Abubakarova E.A. \\ Department of geology, geophysics and eco-geology \\ Complex Research Institute named after Kh.I. Ibragimov of \\ the Russian Academy of Sciences \\ Oil and Gas Institute \\ Grozny State Oil Technical University named \\ after Academician M. D.Millionshchikov \\ Grozny, Russia \\ eliza_ggni@mail.ru

\section{Zaburaeva Kh.Sh.} \\ Department of geology, geophysics and eco-geology \\ Complex Research Institute named after Kh.I. Ibragimov of \\ the Russian Academy of Sciences \\ Oil and Gas Institute \\ Grozny State Oil Technical University named \\ after Academician M. D.Millionshchikov \\ Grozny, Russia \\ eveggne@mail.ru
}

\section{Daukaev A.A.}

Department of geology, geophysics and eco-geology Complex Research Institute named after Kh.I. Ibragimov of the Russian Academy of Sciences

the Academy of Sciences of the Chechen Republic

Chechen State University

Grozny, Russia

daykaev@mail.ru

\section{Badaev S.V.}

Department of geology, geophysics and eco-geology Complex Research Institute named after Kh.I. Ibragimov of the Russian Academy of Sciences

the Academy of Sciences of the Chechen Republic

Grozny, Russia

badaev_sv@mail.ru
Akhmatkhanov R.Sh.

Department of geology, geophysics and eco-geology

Complex Research Institute named after Kh.I. Ibragimov of the Russian Academy of Sciences

the Academy of Sciences of the Chechen Republic Grozny, Russia

rashidgeofizik@mail.ru

\begin{abstract}
The given paper is focused on methods, resources and aims of environmental pollution monitoring of the Chechen republic. It has been revealed that the existing monitoring system does not meet the modern requirements to transfer operational information to the forecasting centers with the aim to be processed and provides measuring of only a small part of the deleterious impurity which is necessary to forecast. To give a quantitative and qualitative description of geo-ecological processes, to forecast the ways of their development, to develop concrete measures in order to prevent negative consequences are
\end{abstract}

possible only when carrying out long-term stationary observations within geo-ecological monitoring.

Keywords - natural resourses, atmospheric air, soil cover, surface waters, pollution, impact, emissions, monitoring.

\section{INTRODUCTION}

The Chechen republic has a multi-industry economic pattern. Its significant parts are oil and gas industry, agro- 
industrial complex, resort and recreational complexes, forestry [4]. The oil and gas industry has had the most negative impact on natural environment components of the republic. The intensive development of oil and gas complex starting with commercial oil production (1893), development and operation of numerous oil-field facilities resulted in the enormous impact on the environment of the Chechen republic, the transformation of natural landscape complexes into naturalanthropogenic and anthropogenic ones [7,10]. Maximum destruction of natural landscapes is observed in the area of Grozny and surrounding territories, where soils, surface and ground waters of urban landscapes have been exposed to massive contamination. Ecological state of the city could not help having an impact on the ecosystem of the republic and territories which are downstream of the rivers Sunzha and Terek [7]. Therefore, environmental pollution monitoring with the aim to preserve the nature, as a human habitat, is the primary task for the Chechen republic.

Preserving the nature and protecting the environment, as a human habitat, is impossible without constant environmental pollution monitoring, situation analysis, determining the severity of exposure and forecasting the condition of environment components [8].

In 2012 in order to develop the unified state ecological monitoring system in the territory of the Chechen republic in accordance with the Federal Law № 7-FZ «on Environmental Protection» dated 10 January 2002, the Federal Law №331 dated 21 November 2011 and Decree of the Russian Government № 177 «on organizing and performing state environmental monitoring (state ecological monitoring)» dated 31 March 2003 a project to develop a territory ecological monitoring system (TEMS) of the Chechen republic was carried out by the former Chechen state committee on ecology [6].

The objects of TEMS are atmospheric air, soil and subsoil, surface and ground waters, vegetable and animal worlds, hunting resources and games' habitats, specially protected natural reservations, social hygiene and human health. According to the present published papers, geo-ecological monitoring is interpreted not only as a monitoring and control system for biosphere state changes but it also includes forecast (prevention) of unfavorable consequences for human vital activities which are caused by these changes as well as their control [11].

Sharp increase of man-caused impact on the environment is connected directly with the rapid development of science and technology, extraction of mineral resources and population growth [2].

According to the Ministry of Health of the Chechen republic, only $20 \%$ of population of the country is apparently healthy. More than $40 \%$ of babies are born unhealthy and $80 \%$ of neonates have different disorders. The high rate of child mortality, an all-time high increase of oncological diseases because of the environment contamination serves as a strong warning about the future ecological disaster in the republic [9].
An acute geo-ecological problem is land pollution by production and consumer waste. The existing ways of domestic solid waste (DSW) recovery are mainly based on the waste burial at dumps and landfills which results in the contamination of surface and ground waters, atmospheric air, soil and vegetation cover. According to different environmental assessments, in the regions of the Northeastern Caucasus up to 300000 tons of waste are dumped every year. Waste storage covers the area of about 150 hectares of the Chechen republic which are not used for agriculture for a long time. In the aggregate to other factors it makes the ecological situation more stressful in the regions [6].

The main task of the given paper is to study geo-ecological problems of the region thoroughly with the purpose to develop scientifically grounded measures for environmental enhancement.

Environmental pollution level depends considerably on the climatic and meteorological conditions of the region which is under consideration. The composition of atmospheric air is specified by the special nature of man-caused impact, territory carrying capacity as well as by the role of photochemical processes [3]. The main determining factors when performing environmental pollution monitoring are as follows: wind (wind velocity and direction), solar radiation, temperature, humidity, pressure (atmospheric pressure, water vapour pressure), atmospheric precipitation (amount of precipitation, average number of precipitation days).

Despite the relatively small territory, the Chechen republic is characterized by considerable diversity of climatic conditions. Here one can meet all transitional types of climate starting with an arid climate of Tersko-Kumskiy semidesert and finishing with a frigid wet climate of the snowy peaks of the mountain range of the Greater Caucasus. Total solar radiation, according to the long-term data of the republic, is equal to $140 \mathrm{kcal} / \mathrm{sm} 2$. The largest amount of solar radiation is in May-July when the sun is higher above the horizon and day length is bigger. Prevailing winds at the plains of the republic are western and eastern ones. In recent years one can observe the increase in wind velocity.

The Chechen republic is one of the territories of the Russian Federation which is the most provided with water resources (both the surface and ground waters). Water resources of the republic are concentrated in rivers, lakes, water-storage reservoirs, glaciers and in the bowels of the earth.

The total amount of rivers is 3198 , the total length of rivers is $6508.8 \mathrm{~km}$. The longest rivers are Terek $(218 \mathrm{~km})$, Sunzha $(205 \mathrm{~km})$, Argun $(125 \mathrm{~km})$, Belka $(83.2 \mathrm{~km})$, Dzhalka $(82.5$ $\mathrm{km})$, Martan (61 km), Gekhi (57 km), Aksay (57 km), Fortanga $(34.7 \mathrm{~km})$, Assa $(32.4 \mathrm{~km})$.

According to the data of the state land registration, the land resources of the Chechen republic account for 1613.9 thousands of hectares. The structure of the land resources of the Chechen republic reveals that the most part of the territory is used for agriculture $-63.1 \%$, land of cities and population centres - 6.5\%, industrial lands, transport lands, communication service lands and lands for other purposes - 
$2.0 \%$, forestry fund lands $-22.9 \%$, reserve land $-8.8 \%$, water fund lands $-0.6 \%$ [4-6].

The aim of this paper is to estimate the efficiency of the existing pollution control system for atmospheric air, surface waters and soil cover as well as to determine actions for further optimization of environmental measures.

\section{METHODS AND MATERIALS}

When monitoring the state of atmospheric air, the study is conducted in order to measure, process and register the results of the concentration of the main air pollutants: carbon monoxide $(\mathrm{CO})$, sulphur dioxide $\left(\mathrm{SO}_{2}\right)$, nitric oxide $(\mathrm{NO})$, ammonia $\left(\mathrm{NH}_{3}\right)$, nitrogen dioxide $\left(\mathrm{NO}_{2}\right)$, ozone $\left(\mathrm{O}_{3}\right)$ and suspended particulate matters of dust. The complex air pollution index (API) is calculated in accordance with the methodology of the regulatory document RD $52.04186-89$, as a sum of average concentrations in MPC values, taking into account the hazard class of the corresponding pollutant:

$$
\text { In }=\sum\left(\mathrm{x}_{\mathrm{i}} / \mathrm{MPC}_{\mathrm{i}}\right) \mathrm{C}_{\mathrm{i}},
$$

due to component control: nitric oxide, nitrogen dioxide, sulphur dioxide, carbon monoxide and ozone.

The study of surface waters is conducted in order to determine organoleptic and physical and chemical properties temperature, smell, sediment, suspended matters, chromaticity, turbidity, transparency, alkalinity, hardness, $\mathrm{pH}$, biochemical oxygen demand (BOD5), chemical oxygen demand (COD) with dichromate and permanganate as the oxidant as well as content of carbon dioxide, ammonia, nitrites, chlorides, sulphates, calcium, magnesium, lead, cadmium, zinc, dissolved oxygen in water.

When estimating surface water quality, hydrochemical water pollution index (WPI) is used in accordance with the State Standard 27065-86 "Water quality. Terms and definitions" by a formula:

$$
W P I=\frac{1}{6} \cdot \sum_{i=1}^{6} \frac{C_{i}}{M P C_{w_{i}}}
$$

of six control components according to the laboratory data: dissolved oxygen, biochemical oxygen demand (BOD5), chemical oxygen demand (COD) with permanganate as the oxidant, lead, cadmium and magnesium.

Estimation of drinking water quality is determined according to the amount of chemical matters, referred to 1 and 2 hazard class and rated by sanitary and toxicological criterion of harmfulness: lead, cadmium and nitrites, and calculated by a formula:

$$
\mathrm{C}_{\text {fact }}{ }^{1} / \mathrm{C}_{\text {add }}{ }^{1}+\mathrm{C}_{\text {fact }}{ }^{2} / \mathrm{C}_{\text {add }}{ }^{2}+\ldots+\mathrm{C}_{\text {fact }}{ }^{\mathrm{n}} / \mathrm{C}_{\text {add }}{ }^{\mathrm{n}} \leq 1
$$

Soil monitoring is carried out by studying the results of the concentration of the priority pollutants obtained after being measured, processed and registered: copper, cadmium, arsenic, zinc, cobalt, manganese, lead, mercury and oil products.

Estimation of chemical pollution of soil, as an indicator of negative health effects for humans, is determined by total pollution index $\left(Z_{c}\right)$ of chemical pollutant concentration, by a formula:

$$
\mathrm{Z}_{\mathrm{c}}=\sum\left(\mathrm{C}_{\mathrm{i}} / \mathrm{C}_{\mathrm{fi}}+\mathrm{C}_{\mathrm{n}} / \mathrm{C}_{\mathrm{fn}}\right)
$$

\section{RESULTS}

In 2015 it was revealed that nitric oxide exceeded the MPC in the air - in April, carbon monoxide exceeded the MPC - in July and October (Figure 1, a, b)

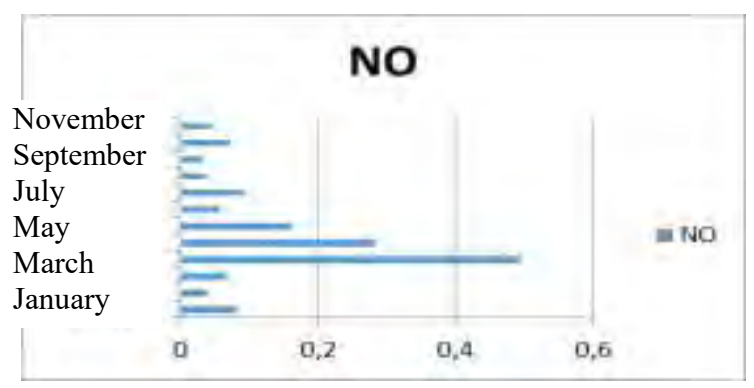

a)

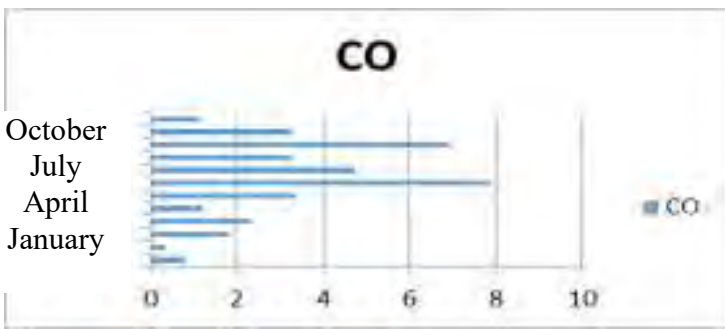

b)

Fig. 1. In 2015 nitric oxide and carbon monoxide exceeded the MPC in the air

In March, April and August 2016 - the excess of nitrogen dioxide was detected in a maximum one-time concentration sample of the air; in June - nitric oxide; in May, September, October - carbon monoxide; in August, October - hydrogen sulphide (Figure 2, a, b, c, d) 


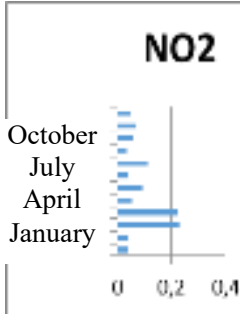

a)

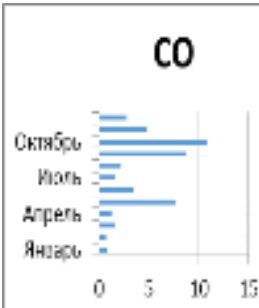

c)

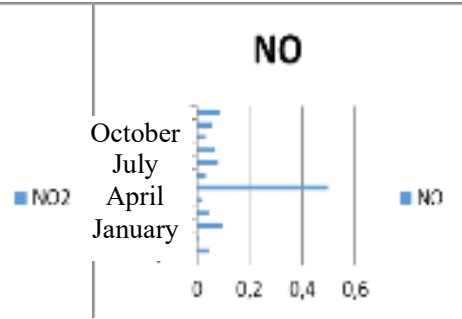

b)

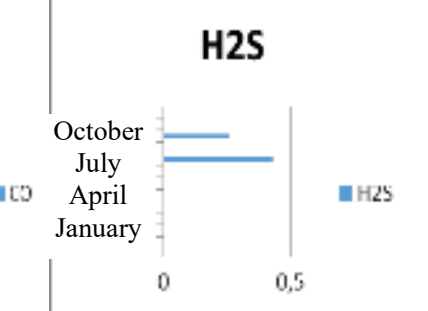

d)
Fig. 2. In 2016 nitrogen dioxide, nitric oxide, carbon monoxide and hydrogen sulphide exceeded the MPC in the air.

In 2017 the excess of nitrogen dioxide was detected in the air - in April; carbon monoxide - in July, September (Figure $3, a, b)$.

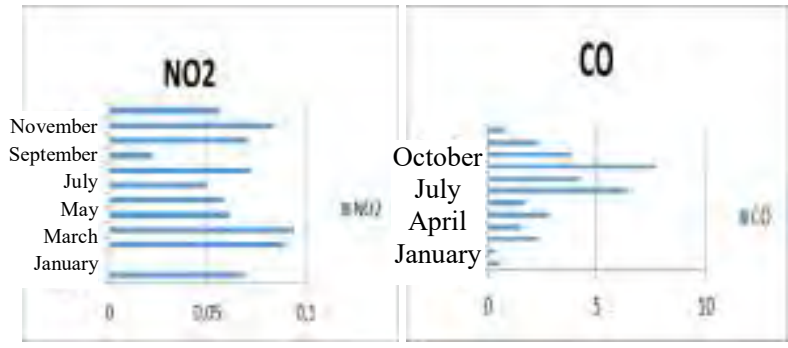

a)

b)

Fig. 3. In 2017 nitrogen dioxide and carbon monoxide exceeded the MPC in the air.

The causes of high concentration of nitric oxide, nitrogen dioxide, carbon dioxide and hydrogen sulphide in the atmosphere are exhaust fumes produced by vehicles, release of pollutants by large and small heat boiler stations, oil production and transportation, climatological conditions [1].

Pollution content in surface waters of the Chechen republic in 2015-2017 (Figure 4, a, b, c, d, e, f, g).

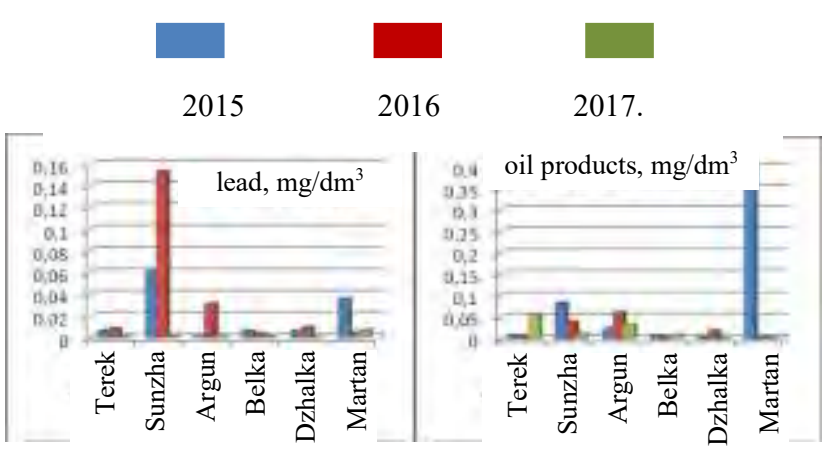

a)

b)

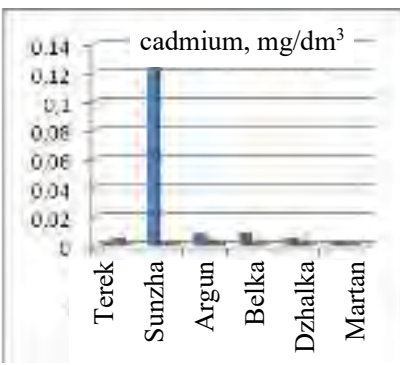

c)

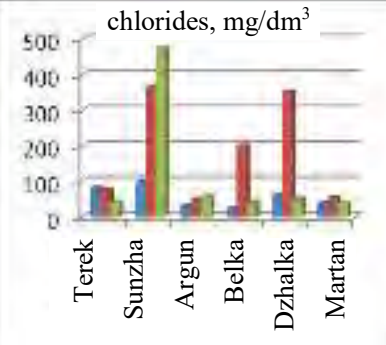

d)

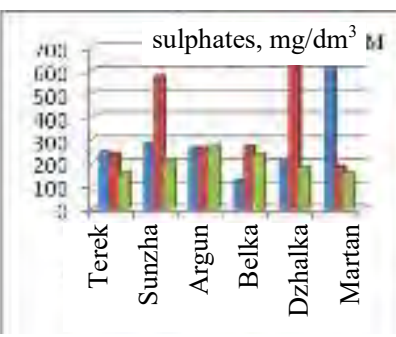

e)

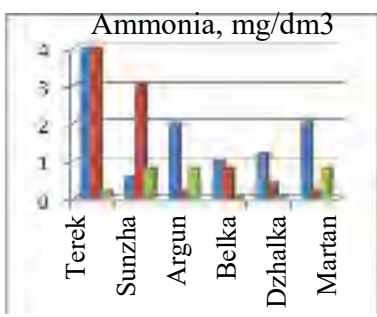

g)

Fig.4. Average annual information and maximum amount of water pollutants within the period of 2015-2017

In 2015 the MPC was exceeded in regard to the indicators of maximum one-time concentration sample:

- ammonia at the stations on Terek, Argun, Martan rivers,

- iron at the stations on Sunzha and Argun rivers,

- $\quad$ high alkalinity at the stations on Martan river,

- hardness exceeding at the stations on Sunzha, Argun and Martan rivers,

- $\quad$ sulphates at the stations on Martan river. 
The MPC was exceeded of averaged and maximum onetime concentrations:

- lead and cadmium at the stations on Sunzha and Martan rivers,

- $\quad$ oil products at the stations on Martan river,

- high biochemical oxygen demand and high biochemical consumption of oxygen at the stations on Martan river.

In 2016 the MPC was exceeded in regard to the indicators:

- ammonia and water colour index at the stations on Terek and Sunzha rivers,

- iron and alkalinity at the stations on Sunzha and Argun rivers,

- chlorides and sulphates at the stations on Sunzha and Dzhalka rivers,

- lead (average and max) at the stations on Sunzha and once at the stations on Argun river,

- cadmium at the stations on Sunzha and Argun rivers,

- biochemical oxygen demand (BOD5), chemical oxygen demand (COD) with permanganate as the oxidant at the stations on Sunzha, Argun and Dzhalka rivers.

In 2016 the MPC was exceeded in regard to the indicators:

- water colour, iron, chlorides, BOD5 and COD with permanganate as the oxidant mainly at the stations on Sunzha river.

The causes of high concentration of pollutants in surface waters are waste waters, agricultural waste waters, accidental oil spills, industrial waste waters, climatological conditions.

When examining the soil covers of settlement zones of the Chechen republic within the given period, the MPC was not exceeded in regard to the indicators of average annual concentration and maximum one-time concentration of pollutants.

The total index of chemical contamination $(\mathrm{Zc})$ in all settlement zones is less than 16 .

\section{CONCLUSION}

The registered total emission of the main pollutants into the air within the given period (average value per year) by stationary sources accounts for - 226939 tons per year including solid pollutants -39.191 tons per year, liquid and gaseous pollutants -187.752 tons per year, among them are sulphur dioxide -4.178 , carbon monoxide -112.682 thousand tons, nitrogen oxides -1.622 thousand tons, hydrocarbons 10.678 thousand tons, volatile organic compounds -14.303 thousand tons, other liquid and gaseous ones - 44.289 thousand tons.

The most polluting plants are OAO Grozneftegas - 94678 tons per year, GUP Chechzhilkomtrans - 23849 tons per year, OAO Chechengas - 12422 tons per year, OOO Firma Stroitel - about 2500 tons per year, GUDP Asfalt-4 - about 2500 tons per year, OOO Yug-stroykompleks - about 2500 tons per year, GUP Dorozhno-stroitelny kombinat - about 2500 tons per year.

Nowadays the major sources of environmental pollution (TEMS objects) of the Chechen republic are exhaust fumes produced by vehicles, release of pollutants by heat boiler stations, oil production and accidental oil spills, industrial waste waters, surface wash and diffuse pollution, climatological conditions.

Industrial wastes are one of the main factors influencing on the condition of ecological systems. As it was shown above, pollutants change chemical composition of water, air and soil that results in many global ecological problems, such as climate change, acid precipitation, a decrease in population of many animal and plant species, lack of clean fresh water and many others [1].

Although environmental preservation and enhancement are a matter of primary importance in the region, extraction of natural resources requires more careful monitoring. The laws and documentation being elaborated do not have enough power to decrease geo-ecological problems.

The present state of environmental pollution monitoring of the Chechen republic is estimated to be satisfactory. However, in order to obtain a more adequate environmental assessment it is necessary:

- to place stationary sites to monitor atmospheric air pollution;

- to increase the frequencies of observations and a number of registered indicators including toxicity;

- to put under observation, with regular sampling frequency, remediated lands (which were disturbed when producing and transporting oil and gas);

- to implement an automated system of industrial emission monitoring (continuous monitoring and early pollution detection).

Environmentally responsible use of natural resources will make it possible to reduce negative impacts on environment significantly since it is extraction, transportation and use of energy resources which, at present, form more than $50 \%$ of general pollution of atmosphere, water bodies and lands [9].

Applying new technologies in industry, producing clean energy, planting of greenery in settlement zones, converting to environmentally safe sources based on solar and water power are primary and essential measures to reduce hazardous substances emissions to the environment.

\section{References}

[1] A. Jolma, A. Lehikoinen, I. Helle, R. Venesjärvi, "A software system for assessing the spatially distributed ecological risk posed by oil shipping," Environmental Modelling \& Software. Vol. 61, pp. 1-11, 2014.

[2] A.A. Daukaev, L.S. Gatzaeva, Z.Sh. Gagaeva, A.V. Sobisevich, "Extraction of mineral resources and eco-geological problems of XX century," Contemporary issues of science and education, № 6, pp. 4447, 2014.

[3] V.S. Rakitin, N.F. Elansky et al., "Changes in trends of atmospheric composition over urban and background regions of Eurasia: estimates 
based on spectroscopic observations," Geography, environment, sustainability, vol.11, no. 2, pp. 84-96, 2018.

[4] State report on the condition and protection of the envoronment of the Chechen Republic in 2015, FGUP «Publishing house «Groznensky rabochiy», Grozny, 2016, pp. 17-22.

[5] State report on the condition and protection of the envoronment of the Chechen Republic in 2016, FGUP «Publishing house «Groznensky rabochiy», Grozny, 2017, pp. 37-44.

[6] State report on the condition and protection of the envoronment of the Chechen Republic in 2017, FGUP «Publishing house «Groznensky rabochiy», Grozny, 2018, pp. 52-60.

[7] I.A. Kerimov, A.A. Daukaev, U.T. Gayrabekov, A.A. Daukaev, "Natural-recreational potential of the mountainous part of the Chechen Republic as a factor of sustainable regional development," Sustainable development of mountainous territories, Vol. 9, № 3 (33), pp. 211-218, 2017.

[8] I.A. Kerimov, M.Ya. Gaysumov, R.S. Akhmatkhanov, S.V. Badaev, "Complex geo-dymamic monitoring of oil and gas fields of TerskoCaspian trough," Herald of the Academy of Sciences of the Chechen Republic, № 2 (19), pp. 24-31, 2013.

[9] K.T. Paytaeva, "Ecological recovery of the Environment of the Chechen Republic," Russian academic journal, Vol. 9, №4, 2009.

[10] U.T. Gayrabekov, A.N. Gunj, T.Kh. Bachaeva, "Physic-Geographic Factors of Oil Development in the Chechen Republic," American Journal of Environmental Sciences, vol. 10 (6), pp. 575-580, 2014.

[11] Kh.Sh. Zaburaeva, Eco-geological grounds for optimizing nature management in mountainous regions of Russia (by way of example of the Northeastern Caucasus): dissertation..., Doctor of geography, 2017, pp. 331 . 